\title{
DIE TAFELN
}

I. Unbekannter Maler. Ölgemälde. 1764 oder 1765

II. Georg Melchior Krauss. Zeichnung. 1776

III. Goethe. Floßbrücke mit Gartenhaus im Weimarer Park. Zeichnung. Zwischen 1776 u. 1782

IV. Joh. Heinr. Lips. Miniatur. 179I

V. Weißer. Gesichtsmaske. 1807

VI. Ferd. Jagemann. Kreidezeichnung, 1817

VII. Heinr. Matthaey. Zeichnung. 1832

VIII. Goethe. Handschrift. 1831 
